\title{
INSTRUMENTAL MEASURING OF THE HARDNESS OF FRESH AND COOKED PARSNIP (Pastinaca sativa)
}

\author{
Miona M. Belović ${ }^{1}$, Mladenka V. Pestorić ${ }^{1}$, Jasna S. Mastilović ${ }^{1}$,̌arko S. Kevrešan ${ }^{1}$, Zoran S. llić ${ }^{2}$, \\ Ljubomir S. Šunić ${ }^{2}$ \\ ${ }^{1}$ University of Novi Sad, Institute of Food Technology, 21000 Novi Sad, \\ Bulevar cara Lazara 1, Serbia \\ ${ }^{2}$ Faculty of Agriculture, Priština-Lešak, 38219 Lešak, Serbia
}

\author{
${ }^{*}$ Corresponding author: \\ Phone: +381214853779 \\ Mobile: +381691986706 \\ E-mail address: miona.belovic@fins.uns.ac.rs
}

\begin{abstract}
The objective of this study was to investigate the application of different instrumental methods for measuring the hardness of fresh and cooked parsnip. Research was carried out on two previously prepared commercial parsnip samples, both fresh and cooked for $5,10,15$ and 20 minutes. Hardness was measured using a TA.XTPlus Texture Analyzer, equipped with different fixtures and load cells. Penetration test was performed on the parsnip discs, while the instrument was equipped with a $5 \mathrm{~kg}$ load cell and a $2 \mathrm{~mm}$ diameter stainless steel flat cylinder probe. Shearing test was conducted on the whole parsnip roots with a $30 \mathrm{~kg}$ load cell and Warner-Bratzler (WB) flat knife blade. The obtained values of the coefficients of variation for both methods indicated that these methods are more suitable for measuring the hardness of fresh parsnip. The results of analysis of variance showed that penetration test generally expressed better differentiation between the samples $A$ and $B$. The greatest change of firmness during cooking was observed after the first 5 minutes, as measured by both methods. Parsnip firmness progressively decreased with increasing cooking time, with less pronounced differences between the cooking times obtained by shearing test. Further experiments should include more representative parsnip samples and more repetitions within the sample in order to make general conclusions. All results should be verified with sensory evaluation of parsnip hardness by an expert panel or a panel of trained assessors.
\end{abstract}

Key words: parsnip, hardness, penetration test, shearing test, cooking time

\section{INTRODUCTION}

The eating quality of vegetables can be measured directly by sensory methods or indirectly by different instrumental methods. Quality parameters should be measured easily for practical reasons and therefore simpler and faster instrumental methods are requested for the quality control of vegetables. Measurement of the basic mechanical properties also provides more reliable and repeatable tests then sensory evaluation (Bourne, 2002). In addition, measurement of food physical cha- racteristics can give a better insight into the plant tissue structure and texture (De Belie et al., 2002), and can be used in the engineering process design (Bajkin et al., 2011). Textural changes during thermal processing of vegetables are often very intensive (Sila et al., 2005). Both cellular turgor and the integrity of cell walls are important components of the hardness of plant materials (Greve et al., 1994). These changes in cell walls are related to the changes in pectin structure caused by 
enzymatic degradation and non-enzymatic reaction of $\beta$-elimination which takes place at higher temperatures (Vu et al., 2004; Sila et al., 2005).

Parsnip (Pastinaca sativa) is a root vegetable originating from Europe and Asia which belongs to the Apiaceae family together with carrot, celery, parsley and fennel (Koidis et al., 2012; Castro et al., 2013). It can be eaten fresh or cooked, usually in soups and stews (Rawson et al., 2010). Parsley, similar to carrot, contains C-17 polyacetylenes in minor quantities, which have been shown in recent studies to have anti-cancer, anti-inflammatory and anti-platelet properties (Rawson et al., 2010; Koidis et al., 2012).

Literature review indicates that carrot is the most examined root vegetable in terms of measuring different textural characteristics of both fresh and processed root. Tests performed on fresh or cooked carrots were usually based on compression, shearing or a combination of both (De Belie et al., 2002). Penetration/puncture test was used by different authors (Lin et al., 1998; De Belie et al., 2002; Rico et al., 2007, Bajkin et al., 2011) to measure the force required to penetrate the carrot disc by probe. Warner-Bratzler blade was also used to measure the force needed to cut through the carrot cylinder (Lin et al., 1998; Rastogi et al., 2008; Ayhan et al., 2008). The application of penetration test and cutting/shearing tests performed with different blade fixtures for measuring the textural characteristics of fresh carrots was examined in our previous research (Pestorić et al., 2013) and it was found that penetration test was the most suitable for the measuring of carrot hardness. However, there are only few research papers dealing with the texture of fresh or thermally treated parsnip. Bajkin et al. (2011) also used puncture test to measure the puncture force in the different measuring points (xylem and phloem tissue) on the fresh parsnip, parsley and celery root.

Considering all mentioned functional properties of parsnip root, as well as its shape which makes it suitable for the instrumental determination, the objective of this research was to apply different instrumen- tal methods to measure the hardness of fresh and cooked parsnip. The change of parsnip firmness during cooking was also examined.

\section{MATERIAL AND METHODS}

\section{Samples}

Two commercial parsnip samples were purchased in market place from different producers, and the size of batch was approximately $3 \mathrm{~kg}$ (about 30 roots per batch). The samples were labelled as sample $A$ and sample $B$, and washed with warm tap water. Afterwards parsnips were peeled with kitchen peeler to remove the root hairs, and stem end as well as lower part of the root (opposite to the stem end) were shredded using a meat slicer (Krups, Germany) before tests (Figure 1).

\section{Texture analysis}

Texture analysis of parsnip was conducted using a TA.XTPlus Texture Analyser (Stable Micro Systems, England, UK). Penetration test and shearing test were performed in order to measure the hardness of fresh and cooked parsnip. Measurements were performed on three roots from each sample.

For penetration test, nine discs with an approximate height of $10 \mathrm{~mm}$ were taken; three from the upper part of the parsnip root (I), three from the middle part (II), and three from the lower part (III) (Figure 1). Height of each parsnip disc was checked using measurement tool (Vernier caliper). The discs were cooked in the following way: 9 discs were put in a sufficiently large volume (about $1.5 \mathrm{~L}$ ) of boiling water $\left(100^{\circ} \mathrm{C}\right)$ for $5,10,15$, and $20 \mathrm{~min}$. After heat treatment they were immediately submerged in cold tap water for a few minutes, and afterwards put on the paper towel to soak up the water. Penetration test was performed with a $2 \mathrm{~mm}$ diameter stainless steel flat cylinder probe (P/2) and a $5 \mathrm{~kg}$ load cell. Instrumental settings were taken from the sample project (GRP1_P2) of the software package (Texture Exponent Software TEE32, version 6,0,6,0, Stable Micro Systems, England, UK), and according to published data (De Belie et al., 2002). 


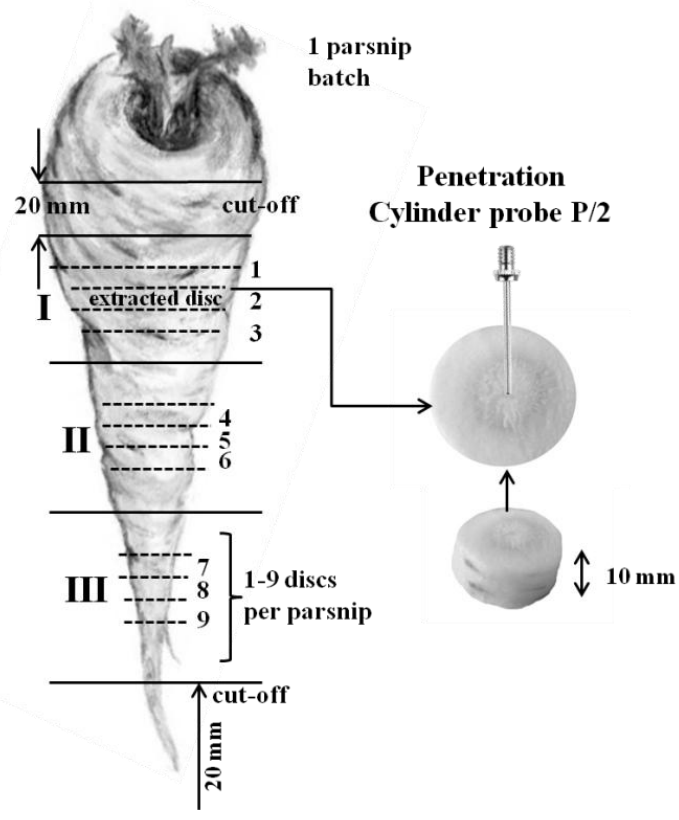

Figure 1. Sample preparation for penetration test

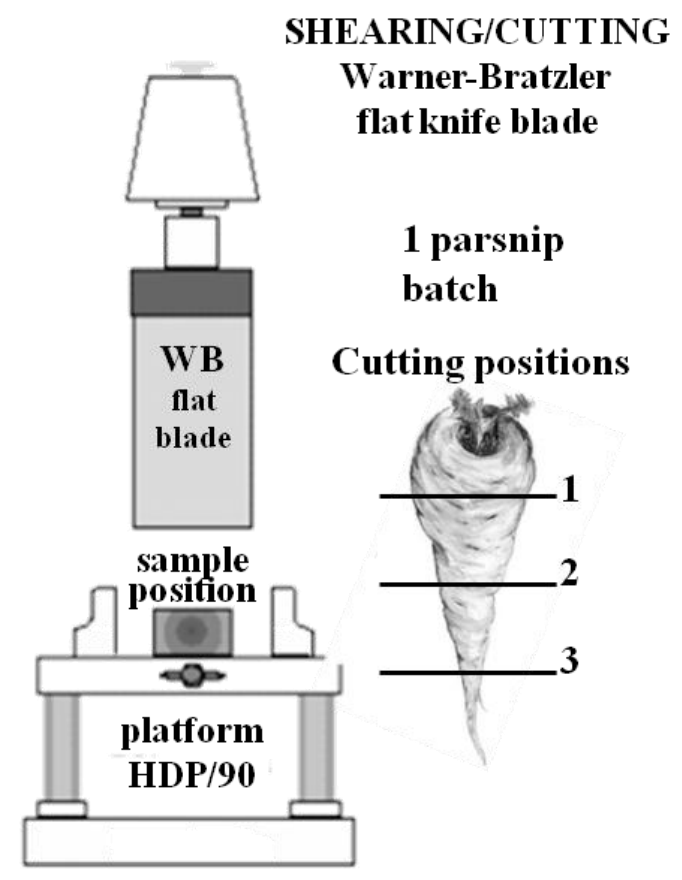

Figure 2. Sample preparation for shearing test

Since according to Bajkin et al. (2011) xylem is the part of carrot and parsnip root with the highest puncture force values, hardness in the centre of parsnip disc has been chosen as the most reliable indicator of changes during cooking. Shearing test was carried out using Warner-Bratzler (WB) flat knife blade fixture and a $30 \mathrm{~kg}$ load cell (Fig. 2). The same cooking procedure was used, with the two whole par- 
snip roots cooked in $2.0 \mathrm{~L}$ of boiling water. During this test, whole root was firstly cut at the middle, then at the middle of the upper part and finally at the middle of the lower part. Applied instrumental settings were taken from the sample project (SAU2_WBB) of the software package (Texture Exponent Software TEE32, version 6,0,6,0, Stable Micro Systems, England, UK), and path length of the WB knife was $40 \mathrm{~mm}$.

\section{Data analysis}

Analysis of variance (ANOVA) and Fisher's least square difference (LSD) test were applied to compare means at 5\% significance level using the statistical data analysis software system STATISTICA (2013). Results were expressed as the mean of replications $\pm S D$ for all measurements. Coefficient of variation (CV) was also calculated.

\section{RESULTS AND DISCUSSION}

Different instrumental methods for determining the hardness of fresh and cooked parsnip were applied, and the coefficient of variation was calculated because it represents a relative measure of error and therefore can be used for the comparison of variation from different methods or scales. Based on the results shown in Table 1. for penetration test and in Table 2. for shearing test, it can be concluded that CVs calculated for both methods are quite large, ranging from 10.82 to even 47.14. However, the lowest CV values $(<25)$ obtained for the fresh parsnip samples imply that both methods are more suitable for the analysis of fresh rather than cooked samples.

Regarding the differentiation of parsnip samples, shearing test was not able to distinguish between neither fresh nor cooked samples A and B. Penetration test differentiated fresh samples, as well as samples cooked for 10 and 15 minutes. In our previous research, penetration test was also the most suitable for differentiation of fresh carrot samples (Pestorić et al., 2013). However, in that research, much lower CVs were obtained for fresh carrots. That could be due to the more heterogeneous texture of parsnip root comparing to the carrot root as measured by the puncture test (Bajkin et al., 2011).

Hardness of fresh parsnip and its change during cooking is presented in Figure 3. The greatest change of hardness measured by both methods was observed after the first 5 minutes. These results are consistent with previous investigations of carrots, whose textural properties are changed most rapidly during the first few minutes of cooking (Greve et al., 1994; De Belie et al., 2002).

Table 1.

Penetration test results of comparison between the parsnip samples

\begin{tabular}{ccccc}
\hline \multirow{2}{*}{ Sample } & \multicolumn{2}{c}{ Sample A } & \multicolumn{2}{c}{ Sample B } \\
\cline { 2 - 5 } & Hardness (g) & CV & Hardness (g) & CV \\
\hline Fresh & $2006 \pm 489^{\mathrm{b}}$ & 24.4 & $2625 \pm 284^{\mathrm{a}}$ & 10.8 \\
Cooked for 5 min & $870 \pm 177^{\mathrm{a}}$ & 20.4 & $870 \pm 410^{\mathrm{a}}$ & 47.1 \\
Cooked for 10 min & $1281 \pm 141^{\mathrm{a}}$ & 11.0 & $953 \pm 209^{\mathrm{b}}$ & 22.0 \\
Cooked for 15 min & $358 \pm 155^{\mathrm{b}}$ & 43.5 & $626 \pm 236^{\mathrm{a}}$ & 37.7 \\
Cooked for 20 $\mathrm{min}$ & $483 \pm 167^{\mathrm{a}}$ & 34.5 & $442 \pm 83^{\mathrm{a}}$ & 18.9 \\
\hline
\end{tabular}

Results are expressed as a mean \pm SD; CV - coefficient of variation; Values with the different superscript in the same row are statistically different $(P<0.05)$

Table 2.

Shearing test results of comparison between the parsnip samples

\begin{tabular}{ccccc}
\hline \multirow{2}{*}{ Sample } & \multicolumn{2}{c}{ Sample A } & \multicolumn{2}{c}{ Sample B } \\
\cline { 2 - 5 } & Hardness $(\mathbf{N} / \mathbf{m m})$ & CV & Hardness $(\mathbf{N} / \mathbf{m m})$ & CV \\
\hline Fresh & $81.1 \pm 17.4^{\mathrm{a}}$ & 21.5 & $102.1 \pm 18.2^{\mathrm{a}}$ & 17.8 \\
Cooked for 5 min & $28.5 \pm 7.0^{\mathrm{a}}$ & 24.6 & $33.2 \pm 9.7^{\mathrm{a}}$ & 29.3 \\
Cooked for 10 min & $12.5 \pm 2.0^{\mathrm{a}}$ & 15.6 & $13.2 \pm 3.3^{\mathrm{a}}$ & 24.7 \\
Cooked for 15 min & $9.4 \pm 4.3^{\mathrm{a}}$ & 45.7 & $10.8 \pm 2.4^{\mathrm{a}}$ & 22.4 \\
Cooked for 20 $\mathrm{min}$ & $11.4 \pm 2.5^{\mathrm{a}}$ & 21.9 & $10.1 \pm 2.0^{\mathrm{a}}$ & 19.5 \\
\hline
\end{tabular}

Results are expressed as a mean \pm SD; CV - coefficient of variation; Values with the different superscript in the same row are statistically different $(\mathrm{P}<0.05)$ 
Significant change of firmness was also observed between 5 and 10 minute of cooking as measured by shearing test, and after that there were no significant changes (Figure $3 b$ ). Trend of firmness decrease of sample A measured by penetration test had anomaly, i.e. parsnips cooked for 10 minutes were significantly firmer than those cooked for 5 minutes (Figure 3a). This could be explained by the great variability within the sample. However, parsnip samples A cooked for 15 and 20 minutes were significantly less firm than those mentioned above, indicating that longer thermal treatment nevertheless affected parsnip texture. Sample B expres- sed normal trend of firmness decrease, with significant differences observed between $10^{\text {th }}$ and $15^{\text {th }}$ minute of cooking, as well as between 15 and 20 minute. This marked difference between the samples' trend of firmness decrease could be also explained by the fact that parsnip is firmer than carrot, and that 20 minutes of cooking is not enough time to observe the general trend of firmness decrease, regardless of the examined sample. Therefore, more different samples and a larger number of repetitions (tested roots) within the sample as well as longer cooking times are required to obtain the general conclusion.
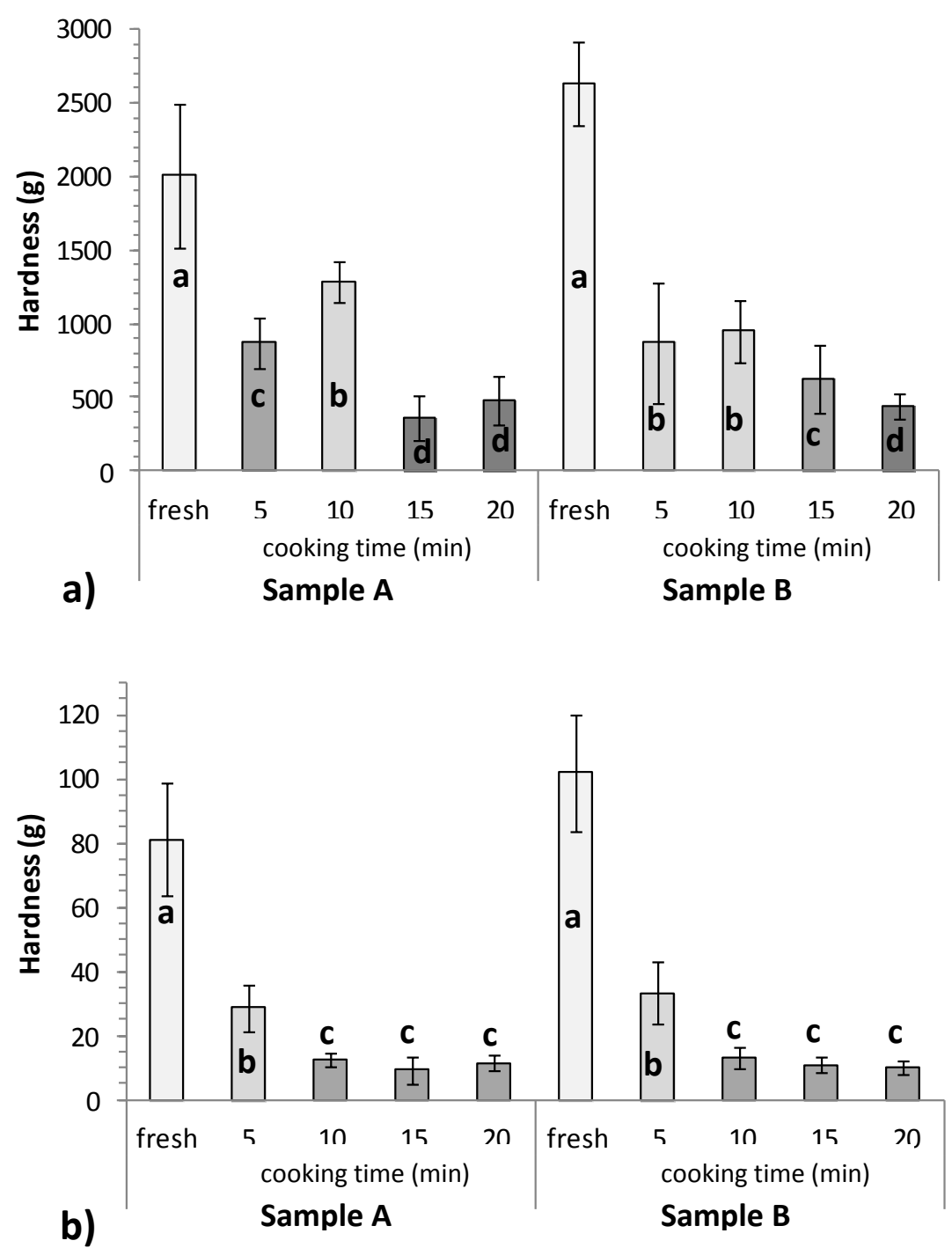

Figure 3. Hardness of fresh parsnip samples $A$ and $B$ and its change during cooking:

a) penetration test, b) Warner-Bratzler flat blade shearing test;

Columns marked with different letters indicate significant difference 
These results should also be confirmed by the sensory evaluation of firmness by a trained panel.

\section{CONCLUSIONS}

Generally, penetration test was more suitable than shearing test for the measuring of fresh parsnip hardness, achieving both low CVs and sample differentiation. Further experiments on both fresh and cooked parsnips should be conducted on larger number of representative samples. Measurements should also be performed with more repetitions within the sample and with longer cooking times in order to draw general conclusion. In addition, results should be related to the hardness evaluated by an expert panel or a panel of trained assessors.

\section{ACKNOWLEDGEMENT}

This paper is a result of the researches within the project III 46001, financed by the Ministry of Education, Science and Technological Development, Republic of Serbia.

\section{REFERENCES}

1. Ayhan Z., Eştürk O., Taş E. (2008). Effect of Modified Atmosphere Packaging on the Quality and Shelf Life of Minimally Processed Carrots. Turkish Journal of Agriculture and Forestry, 32, 57-64.

2. Bajkin, A., Ponjičan, O., Radomirović, D., Babić, M., Radojčin, M. (2011). Determination of physical characteristics of root vegetables with puncture test. Journal on Processing and Energy in Agriculture (former PTEP), 15 (3), 130-133.

3. Bourne M. C. (2002). Food texture and viscosity: concept and measurement. Second Edition, Academic Press, An Elsevier Science Imprint.

4. Castro A., Bergenståhl B., Tornberg E. (2013). Effect of heat treatment and homogenization on the rheological properties of aqueous parsnip suspensions. Journal of Food Engineering, 117, 383-392.

5. De Belie N., Laustsen A.M., Martens M., Bro R., De Baerdemaeker, J. (2002). Use of physicochemical methods for assessment of sen- sory changes in carrot texture and sweetness during cooking. Journal of Texture Studies, 33, 367-388.

6. Greve L. C., Shackel K. A., Ahmadi H., McArdle R. N., Gohlke J. R., Labavitch J. M. (1994a). Impact of Heating on Carrot Firmness: Contribution of Cellular Turgor. Journal of Agricultural and Food Chemistry, 42, 2896-2899.

7. Koidis A., Rawson A., Tuohy M., Brunton N. (2012). Influence of unit operations on the levels of polyacetylenes in minimally processed carrots and parsnips: An industrial trial. Food Chemistry, 132, 1406-1412.

8. Lin T. M., Durance T. D., Scaman C. H. (1998). Characterization of vacuum microwave, air and freeze dried carrot slices. Food Research International, 31, 111-117.

9. Pestorić M., Belović M., Mastilović J., Kevrešan Ž. (2013). Different instrumental methods for measuring the textural characteristics of fresh carrots. Proceedings of the III International Congress "Engineering, Environment and Materials in Processing Industry", Jahorina, Bosnia and Herzegovina, 755-763.

10. Rastogi N. K., Nguyen L. T., Balasubramaniam V. M. (2008). Effect of pretreatments on carrot texture after thermal and pressure-assisted thermal processing. Journal of Food Engineering, 88, 541-547.

11. Rawson A., Koidis A., Rai D. K., Tuohy M., Brunton N. (2010). Influence of Sous Vide and Water Immersion Processing on Polyacetylene Content and Instrumental Color of Parsnip (Pastinaca sativa) Disks. Journal of Agricultural and Food Chemistry, 58, 7740-7747.

12. Rico D., Martýn-Diana A. B., Frýas J. M., Barat J. M., Henehan G. T. M., Barry-Ryan C. (2007). Improvement in texture using calcium lactate and heat-shock treatments for stored ready-toeat carrots. Journal of Food Engineering, 79, 1196-1206.

13. Sila D. N., Smout C., Vu S.T., Van Loey A., Hendrickx M. (2005). Influence of Pretreatment Conditions on the Texture and Cell Wall Components of Carrots during Thermal Processing. Journal of Food Science, E: Food Engineering and Physical Properties, 70, E85E91.

14. STATISTICA (Data Analysis Software System) (2013), version 12.0. StatSoft Inc., Tulsa, OK, USA (www.statsoft.com).

15. Vu T. S., Smout C., Sila D. N., LyNguyen B., Van Loey A. M. L., Hendrickx M. E. G. (2004). Effect of preheating on thermal degradation kinetics of carrot texture. Innovative Food Science and Emerging Technologies, 5, 37-44. 


\title{
ИНСТРУМЕНТАЛНО МЕРЕЊЕ ТВРДОЋЕ СВЕЖЕГ И КУВАНОГ ПАUTPHAKA (Pastinaca sativa)
}

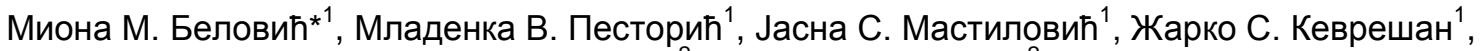 \\ Зоран С. Илић ${ }^{2}$ Љубомир С. Шунић \\ ${ }^{1}$ Универзитет у Новом Саду, Научни институт за прехрамбене технологије у Новом Саду, \\ 21000 Нови Сад, Булевар цара Лазара бр. 1, Србија \\ ${ }^{2}$ Пољопривредни факултет, Приштина-Лешак, 38219 Лешак, Србија
}

\begin{abstract}
Сажетак: Циљ овог истраживања је примена различитих инструменталних метода за мерење тврдоће свежег и куваног паштрнака. Истраживање је спроведено на два претходно припремљена комерцијална узорка паштрнака, како свежем, тако и куваном 5, 10, 15 и 20 минута. Тврдоћа је измерена помоћу TA.XTPlus Texture Analyzer-a, коришћењем различитих наставака и мерних ћелија. Тест пробоја је изведен на дисковима паштрнака, при чему је инструмент био опремљен равном цилиндричном сондом од нерђајућег челика пречника $2 \mathrm{~mm}$ и мерном ћелијом од $5 \mathrm{~kg}$. Тест смицања је спроведен на целом корену паштрнака помоћу мерне ћелије од $30 \mathrm{~kg}$ и Warner-Bratzler-овог (WB) равног ножа. Добијене вредности коефицијената варијације за обе методе указују да су ове методе погодније за мерење тврдоће свежег паштрнака. Резултати анализе варијансе указују да тест пробоја уопштено врши боље раздвајање узорака А и В. Највећа промена чврстоће током кувања је уочена након првих 5 минута кувања, измерено обема методама. Чврстоћа паштрнака се прогресивно смањивала са повећањем времена кувања, са мање израженим разликама између времена кувања добијеним помоћу теста смицања. Даљи експерименти би требало да укључе још репрезентативних узорака паштрнака и више понављања унутар узорка да би се извукли општи закључци. Сви резултати требало би да се верификују сензорском оценом чврстоће паштрнака од стране експертског панела или панела тренираних оцењивача.
\end{abstract}

Кључне речи: паштрнак, тврдоћа, тест пробоја, тест смицања, време кувања

Received: 24 March 2014

Accepted: 9 May 2014 